\title{
ENHANCEMENT OF THE ACTIVITY OF FERRUGINEOL BY N-PENTANOL IN AN ATTRACTANT BAITED TRAP FOR THE COCONUT PEST, RHYNCHOPHORUS FERRUGINEUS F. (COLEOPTERA: CURCULIONIDAE)
}

\author{
NEELAKANTHI E. GUNAWARDENA and H.M.W.K.B. HERATH \\ Department of Chemistry, University of Kelaniya, Kelaniya.
}

(Received: 30 September 1994; accepted: 02 June 1995)

\begin{abstract}
Short chain alcohols, known attractants for the coconut pest, Rhynchophorus ferrugineus F.(Coleoptera: Curculionidae), were used to improve a 4-methyl-5-nonanol (ferrugineol) baited trap for the weevil. In a Y shaped olfactometer-choice test, $68 \%$ weevils selected the ferrugineol baited arm. n-Propanol and n-pentanol elicited responses in $80 \%$ and $79 \%$ respectively of weevils. Combinations of n-pentanol: ferrugineol (1:1) and n-propanol: ferrugineol (1:1) did not show increased activity ( $80 \%$ and $82 \%$ selection respectively). In a field assay, n-propanol and n-pentanol baited traps caught no weevils whereas ferrugineol caught a mean number of 0.42 weevils/ trap/day. A 1:1 combination of ferrugineol with five alcohols viz. n-propanol, n-butanol, n-pentanol, n-hexanol and n-nonanol were field tested as baits for possible enhancement of activity of ferrugineol. A significantly higher catch of 0.85 weevils/day/trap, ( $p<0.05$, Scheffe's test) was obtained with ferrugineol: n-pentanol. Ferrugineol:hexanol baited traps caught 0.45 weevils/trap/day which was only marginally higher than that of the standard, ferrugineol. Other combinations caught fewer weevils (range 0.05-0.2 weevils/trap/day) and the control trap caught no weevils.
\end{abstract}

Key words: Attractant baited trap, coconut pest, ferrugineol, pentanol, Rhynchophorus ferrugineus.

\section{INTRODUCTION}

Rhynchophorus ferrugineus F.(Coleoptera: Curculionidae), commonly known as the red weevil is a serious pest of coconut in many countries ${ }^{1}$ including Sri Lanka. ${ }^{2,3}$ Affected palms are saved only if treated early during infestation. ${ }^{4}$ The use of an electronic device ${ }^{5}$ and sterile insect technique ${ }^{6}$ have failed to control the red weevil. An early warning system in coconut estates is needed to reduce pest attacks. An attractant baited trap would be suitable. for this purpose since farmers can then take preventive measures. ${ }^{4}$

The sap oozing from the wounded coconut bark or the fermented sap from the inflorescences (toddy) is a known natural attractant for the red weevil.? Using electroantennography (EAG), the short chain alcohols n-pentanol and $\mathrm{n}$-hexanol were shown to have a pronounced effect on the antennae of the red weevil. ${ }^{8}$ A combination of 4-methyl-5 nonanol (ferrugineol) and 4-methyl-5nonanone (ferrugineone) has been identified as an aggregation pheromone in red weevil. ${ }^{9}$ Using the more active pheromone viz. ferrugineol, in a baited trap, a catch of 0.23 weevils/trap/ day was observed from the Districts of Kurunegala and Gampaha. ${ }^{10}$ The present paper reports the results of laboratory and field evaluation of the activities of short chain alcohols, ferrugineol and a 1:1 combinations $(\mathrm{v} / \mathrm{v})$ of both as attractants for the red weevil. 


\section{METHODS AND MATERIALS}

Test compounds: Ferrugineol (99\% pure by GLC) was obtained by synthesis. n-Propanol, n-butanol, n-pentanol, n-hexanol and n-nonanol were purchased from Aldrich (UK).

Laboratory bioassay: One $\mathrm{mg} / \mathrm{ml}$ solutions of attractants under investigation were made in hexane (Merck, Germany). Baits were prepared by absorbing $50 \mu \mathrm{g}$ of the compound onto filter paper strips and allowing the solvent to evaporate. Combinations of attractants were used as a 1:1 (v/v) mixture. Controls were prepared by absorbing hexane onto filter paper strips.

Using a Y- shaped olfactometer ${ }^{11}$ the behavioural assay was carried out by the choice test ${ }^{7}$ with the following features. Each bait under investigation was kept in arm A while the blank was in arm B. A tube containing batches of males and females ( $<2$ wks old) was connected to tube $\mathbf{C}$ just prior to the experiment. A slow stream of air (2-4 l/min) was then passed through arms $\mathbf{A}$ and $\mathbf{B}$ upto the arm C. Insects which encountered air containing the attractant proceeded towards the $\mathrm{Y}$-junction and made their selection. Among those weevils moving forward, the ability to select the baited arm was considered as the criterion for attractivity. Hence the number of insects in each arm was noted after 3 min. Batches of 5-12 unsexed weevils were used at a time. Replicates ( $n=10-13)$, in a staggered manner was run on each bait. Mean \% of weevils attracted to baited and non-baited arms were compared by the chi-square test and activities of different baits by ANOVA followed by Scheffe's test.

Field assay: Following a previously described method, ${ }^{10}$ ferrugineol was used as a neat liquid incorporated in a capillary with a diameter of $1.5 \mathrm{~mm}$. The average rate of evaporation of ferrugineol was kept at $0.4 \mathrm{mg} / 24 \mathrm{~h}$ at a field temperature of $31^{\circ} \mathrm{C}$. All other short chain alcohols except n-nonanol were first mixed with an equal volume of paraffin oil in order to reduce the rate of evaporation. A capillary filled with paraffin oil was used as the control. Open plastic buckets (51,21 cm diam, $17 \mathrm{~cm}$ height) filled with soap water up to $2 \mathrm{~cm}$ below the top were used as traps. These were hung $30 \mathrm{~m}$ apart, on coconut palms at $1.6 \mathrm{~m}$ height in coconut fields in the District of Gampaha (Kadawata \& Waragoda) on a random basis. Each capillary loaded with a test substance was placed in a small glass vial ( $2 \mathrm{ml}$ ) and was suspended inside each bucketjust above the water level. The trap catch was noted daily for a period of 21 days.

\section{RESULTS}

Laboratory bioassay: The results of the olfactometer bioassay on attractivity of single compounds and combinations, are shown in Table 1 . The combinations of n-pentanol: ferrugineol and n-propanol: ferrugineol did not elicit significantly higher activities than the corresponding alcohols used alone.

Field assay: The results of the field trapping with single attractants was as follows. A catch of 0.42 weevils/trap/day was obtained for ferrugineol whereas 
n-pentanol or n-propanol as well as the control (blank trap) did not trap any weevils. In the case of ferrugineol combinations, those with n-propanol, n-butanol and n-nonanol did not enhance the trap catch. Of all combinations, ferrugineol: $n$-pentanol had the highest mean trap catch of $0.85 /$ trap/day which was significantly different $(p<0.05$, ANOVA, Scheffe's test) from those of the others including that of ferrugineol: $n$-hexanol combination which caught 0.45 . weevils/trap/day. The latter however did not differ significantly from the standard, ferrugineol. The records of the daily trap catch of weevils showed a fairly uniform response pattern of $R$. ferrugineus to the the most promising bait, ferrugineol: n-pentanol over the experimental period of 21 days.

Table 1: Response of $\boldsymbol{R}$. ferrugineus to different attractants in an olfactometer.

\begin{tabular}{|c|c|c|c|}
\hline $\begin{array}{l}\text { Test } \\
\text { substance }\end{array}$ & $\begin{array}{l}\text { Total No. } \\
\text { of weevils* }\end{array}$ & $\begin{array}{l}\text { No. of replicates } \\
(n)\end{array}$ & $\begin{array}{c}\% \text { Mean of insects } \\
\text { attracted to } \\
\text { baited arm }\end{array}$ \\
\hline $\begin{array}{r}\text { Ferrugineol } \\
(50 \mu \mathrm{g})\end{array}$ & 60 & 10 & $\begin{array}{r}68.6^{\mathrm{b}} \\
( \pm 2.2)\end{array}$ \\
\hline $\begin{array}{l}\text { n-Pentanol } \\
(50 \mu \mathrm{g})\end{array}$ & 111 & 13 & $\begin{array}{r}79.0^{\circ} \\
( \pm 4.0)\end{array}$ \\
\hline $\begin{array}{l}\text { n-Propanol } \\
(50 \mu \mathrm{g})\end{array}$ & 97 & 11 & $\begin{array}{r}80.3^{4} \\
( \pm 4.4)\end{array}$ \\
\hline $\begin{array}{l}\text { Ferrugineol }+ \\
\text { n-pentanol }(1: 1, \mathrm{v} / \mathrm{v})\end{array}$ & 60 & 10 & $\begin{array}{r}80.2^{\mathrm{a}} \\
( \pm 5.2)\end{array}$ \\
\hline $\begin{array}{l}\text { Ferrugineol }+ \\
\text { n-propanol }(1: 1, \mathrm{v} / \mathrm{v})\end{array}$ & 60 & 10 & $\begin{array}{r}82.1^{\mathrm{a}} \\
( \pm 4.8)\end{array}$ \\
\hline $\begin{array}{l}\text { Distilled water } \\
\text { (Control) }\end{array}$ & 60 & 10 & $\begin{array}{r}6.66^{c} \\
( \pm 4.4)\end{array}$ \\
\hline
\end{tabular}

"Each batch consisted of 5-12 unsexed weevils. "Standard Deviation given in parentheses. a.b.c Means followed by the same letter are not significantly different $(p<0.01$, ANOVA, Scheffe's test).

\section{DISCUSSION}

The fermenting coconut sap, a known natural attractant of the red weevil was reported to consist of short chain alcohols from $\mathrm{C}-2$ to $\mathrm{C}-5 .{ }^{12}$ The potency of n-pentanol, n-propanol, n-hexanol and n-heptanol as attractants compared to the other members in the series was shown previously by an electroantennogram assay. ${ }^{8}$ Ferrugineol, the more attractive component of the aggregation pheromone of the red weevil was shown to lure the red weevils in the field although its 
attractivity was poor. ${ }^{10}$. The present behavioural activity comparison by laboratory and field assay distinguished the two different characters of the short chain alcohols and ferrugineol. Short chain alcohols were more effective in attracting the walking weevils from a short distance compared to ferrugineol. Ferrugineol was the only attractant effective in luring weevils from a distance in the field. The long range attractant property of ferrugineol synergised with the short range attractant property of $n$-pentanol. The laboratory bioassay has failed to show the increased attraction of the combination pentanol: ferrigineol over a short distance. Since n-pentanol is a major alcohol constituent of coconut sap ${ }^{12}$ and is present in volatiles emanating from wounded coconut bark, ${ }^{13}$ it is likely that in nature, the power of the aggregation pheromone is enhanced by n-pentanol. However n-propanol and n-butanol which are also more minor constituents of the volatiles from coconut bark do not show synergism with ferrugineol.

The attraction of Rhynchophorus species to palm tissue has long been known. A fresh coconut petiole baited trap has been reported for the red weevil with an effeciency of 0.17 weevils/trap/ day. ${ }^{14}$ The metal box type trap used in this operation is however costly (approximately $R s$ 600). A large number of aggregation pheromones of the species $R$ hynchophorus identified in recent years have been experimented in the field together with palm tissue for enhanced attraction. ${ }^{9,15.16}$ For example for the trapping of red weevil with either ferrugineol alone or a mixture of ferrugineol: ferrugineone (10:1) have been used together with freshly cut coconut wood pieces $(2 \mathrm{~kg}$ ) treated with diazinon insecticide in bucket traps. ${ }^{9}$ However the weekly replacement of fresh coconut tissue in such traps is not practical in large coconut estates. Maximal trap catch on the fifth day and a decline thereafter has been observed in the above trap in contrast to a uniform trap catch observed throughout in the ferrugineol: pentanol baited trap. Simplicity, a long life time of the bait, the uniformity and the high trap catch indicates that the present approach is potentially useful for controlling the red weevil.

\section{Acknowledgement}

We thank NARESA for a research grant (RG/92/C/2) and S. Dissanayake, C. Meegoda and A. Swarnakanthi of the Department of Chemistry, University of Kelaniya for assistance.

\section{References}

1. Nirula K. K. (1956). Investigations on the pests of coconut palm. The Indian Coconut Journal 28-40.

2. Pinto J. L. J. G. (1984). Red weevil, pest of coconut. Coconut Bulletin, Coconut Research Board of Sri Lanka 1(2): 36.

3. GTZ, CARP (1993). Report. Agricultural Research Management Project Discussion Document, Vol. 4. 
4. Coconut Research Institute (1976). Control of the red weevil. Leaflet No. 36 .

5. Coconut Research Institute (1971): An electronic device for the detection of the red weevil infestation. Leaf let.

6. Kloft W., Kloft E. S., Kanagaratnam P. \& Pinto J.L.J.G. (1986). Studies on the use of radio isotopes for the control of the red palm weevil Rhynchophorus ferrugineus F. by the sterile insect technique. Cocos 4: 11-17.

7. Gunawardena N.E. \& Gunatilake R. (1993). Preliminary studies on a host attractant of the coconut pest, Rhynchophorus ferrugineus (Coleoptera: Curculionidae). Journal of the National Science Council of Sri Lanka 21(1): 93-101.

8. Gunawardena N. E. \& Kern F. (1994). Electroantennogram responses of the coconut pest, Rhynchophorus ferrugineus (Coleoptera: Curculionidae) to alcohols. Journal of the National Science Council of Sri Lanka 22(1): 25-33.

9. Hallet R.H., Gries R., Borden J.H., Czyzewska E., Oehschalager A.C., Pierce H.D. jr., Angerilli N.P.D. \& Rauf A. (1993). Aggregation pheromones of two Asian palm weevils, Rhynchophorus ferrugineus and $R$. vutneratus. Naturwissenschaften 80: 328- 331.

10. Gunawardena N.E. \& Bandarage U.K (1995). 4-methyl-5-nonanol(Ferrugineol), as an aggregation pheromone of the coconut pest, Rhynchophorus ferrugineus F. (Coleoptera: Curculionidae): synthesis and use in a preliminary field assay. Journal of the National Science Council of Sri Lanka 23(2): 71-79.

11. Gunawardena N. E., Attygalle A. B. \& Herath H. M. W.K. B. (1989). The sex pheromone of the brinjal moth Leucinoides orbonalis Guenee (Lepidoptera): problems and perspectives. Journal of the National Science Council of Sri Lanka 17(2): 161-171.

12. Samarajeeva U. \& Adams M.A. (1983). Biochemistry of fermentation in toddy and production of Arrack. Vidyodaya Journal of Arts and Science Letters 11: (1\& 2): 41-53.

13. Jaffe K., Sanchez P., Cerda H., Hernandez J.V., Jaffe R., Urdaneta, Guerra, G., Martinez R. \& Miras B. (1993). Chemical ecology of the palm weevil, Rhynchophorus palmarum L. (Coleoptera: Curculionidae): attraction to host plant and to a male produced aggregation pheromone. Journal of Chemical Ecology 19(8): 1703-1719.

14. Coconut Research Institute (1975). Report of the Crop Protection Division. Ceylon Coconut Quarterly 26: 51-56. 
15. Rochart D., Malosse C., Lettere M., Ducrot P., Renou M. \& Descoins C. (1991). Male-produced aggregation pheromone of the American palm weevil, Rhynchophorus palmarum (L)(Coleoptera: Curculionidae): collection, identification, electrophysiological activity and laboratory bioassay. Journal of Chemical Ecology 17(11): 2127-2141.

16. Gries G., Gries R., Pereż A.L., Oehlschlager A.C., Gonzales L.M., Pierce H. D. jr., Kouda M., Zebeyou M.\& Nanou N. (1993). Aggregation pheromone of the African palm weevil, Rhynchophorus phoenicis F. Naturwissenschaften 80: $90-91$. 